\title{
Forgiveness as Institution: A Merleau-Pontian Account
}

Recent literature on forgiveness suggests that a successful account of the phenomenon must satisfy at least three criteria. First, an account must be able to explain how the act of forgiving, which involves the forgoing of resentment toward a purported wrongdoer, can be responsive to reasons. Following Pamela Hieronymi and Owen Ware, we can call this first criterion the articulateness condition. ${ }^{1}$ Second, an account of forgiveness must be able to explain how forgiveness can be uncompromising. According to Hieronymi, this means that the account must be able to explain how one can rationally choose to forgo resentment toward the wrongdoer while nonetheless holding fixed three different but closely related judgments: that the act for which the person is to be forgiven really was a serious wrong that deserves to be taken seriously, that the wrongdoer is responsible for her act, and that the forgiver deserved not to have been wronged. ${ }^{2}$ Following Hieronymi and Ware once again, we can call this the uncompromisingness condition. And finally, an adequate account must be able to explain how forgiveness is elective; it must make sense of our intuition that forgiveness is a kind of gift, that it is not something that we owe to the wrongdoer, such that she could demand it as her due. ${ }^{3}$

These three criteria are not logically inconsistent, but the history of reflection on the ethics of forgiveness nonetheless suggests that they are in tension. Accounts that

\footnotetext{
${ }^{1}$ Hieronymi, (2001, p. 530); Ware (2014, p. 247).

2 Hieronymi, (2001, p. 530).

3 Sussman, (2005, p. 87); Allais (2013, p. 642).
} 
emphasize articulateness and uncompromisingness tend to suggest an excessively deflationary understanding of electiveness, while those that emphasize electiveness tend to weaken the safeguards that keep forgiveness distinct from condonation, excuse, or mere servility. What I want to argue in this paper is that we can do justice to all three conditions by understanding forgiveness in terms of the concept of institution that Maurice Merleau-Ponty developed in his work from the early- to mid-1950s. In what follows, then, I will begin by explaining why it is so important that an account of forgiveness satisfy the three conditions and why it has been so difficult to do so. I will then propose an understanding of forgiveness that treats it as an act of institution in Merleau-Ponty's sense, emphasizing the ways in which this conception makes sense of our intuitions about articulatneness, uncompromisingness, and electiveness better than rival accounts.

\section{The Articulateness and Uncompromisingness Conditions}

A very large percentage of the literature on forgiveness takes as its beginning point the conception advanced by Bishop Butler in the eighth and ninth of his Fifteen Sermons, according to which forgiveness is the forswearing of excessive resentment. 4 When we feel resentment, according to Butler, what we resent is a perceived injustice and never a mere natural harm. 5 We do not resent a tree when it falls on our car, for example, but we would certainly resent a person who cut the tree down with the intent of making it fall there. This fact gives us a clue as to the reason why this passion has been implanted

\footnotetext{
4 This is sometimes called the "standard view of forgiveness." Kekes (2009, pp. 488-506); Zaibert (2009, pp. 365-393).

5 Butler (2006, 92 [VIII.7]). Numbers in brackets refer to the sermon and section numbers respectively.
} 
within us: It is because people "are plainly restrained from injuring their fellow creatures by fear of their resentment; and it is very happy that they are so, when they would not be restrained by a principle of virtue." 6 The passion of resentment is valuable to us, in short, because it helps us to prevent and to defend ourselves against moral wrongs. But resentment is not unambiguously good: Because we are typically bad judges in our own cases, we often resent excessively.7 When this happens, resentment can easily turn into malice and the desire for revenge, which give rise to more injuries and thus to more resentment. 8 And so even though resentment has a valuable role to play in our moral lives, it is also important that we forgo our resentment in order to avoid these evils. But this account needs further refinement, since we can easily imagine cases of renouncing excessive resentment that we would not want to count as cases of forgiveness. It is in refining the account of forgiveness so that it does not include too much that the necessity of the articulateness and uncompromisingness conditions becomes apparent. Let us begin with the articulateness condition. As Pamela Hieronymi notes, both resenting and forgiving involve changes in our judgments about others that we believe to be justified by good reasons. ${ }^{9}$ For every case of forgiveness, then, we should be able, in principle at least, to give the reasons justifying our change in judgment. If there is no such justification to be given, then the forgoing of resentment will have been something

\footnotetext{
${ }^{6}$ Butler (2006, p. 94 [VIII, 14]).

7 Butler (2006, p. 93 [VIII, 8,9]).

${ }^{8}$ Butler (2006, p. 97 [IX, 5]).

9 Hieronymi (2001, p. 530).
} 
other than forgiveness. If I were to stop resenting another person simply because I had forgotten about the wrong, for example, I would not allow myself to claim any moral credit for having exercised the virtue of forgiveness. This would also be the case if I had not forgotten the wrongdoing, but nonetheless my resentment had been slowly eroded by the passage of time. ${ }^{10}$ In both of these cases, my change in attitude toward the wrongdoer would not have been based on any kind of judgment that I could stand behind; it would be closer to the truth to say that the change happened to me. It may turn out to have been for the best that my feelings toward the wrongdoer developed in these ways, and there may well have been good reasons for me to encourage those developments, but if my forgoing of resentment was not responsive to articulable reasons, then what happened will not have been forgiveness properly speaking.

But not just any articulable reason will do. The point here is not merely that some reasons to forgive are bad, such that we would make a mistake if we acted on them. Rather, there are some reasons that would make the forgoing of resentment something importantly different from forgiveness. These are the reasons that are ruled out by the uncompromisingness condition. First, our decision to forgive cannot be based on our having concluded that the other person had not actually done the wrong thing, all things considered. This is because if the person has not done the wrong thing, there is nothing to forgive. This point becomes especially clear if we adopt the point of view of the target of resentment: Surely we would find it ridiculous, and probably insulting as well, to be told that we have been forgiven on the grounds that the thing we had done was not actually

10 Jankélévitch (2005, pp. 13-56). 
wrong. To forgo resentment in such a case would not be to forgive, but rather to justify. ${ }^{11}$ Second, our decision to forgive cannot be based on our concluding that the other person did the wrong in question, but should not be held responsible for it. If we found out that a person had committed a wrong because he was suffering from severe mental illness, for example, or because he had been drugged against his will, then our forgoing of resentment would take the form of excusing the wrongdoer, and not of forgiving him.12 Once again there would be nothing to forgive, since what we forgive are unjustified, unexcused wrongs.

The third reason one must not have for forgoing resentment is that one does not deserve to be treated well. Immanuel Kant develops a version of this idea in The Metaphysics of Morals, where he argues that we have a duty to be forgiving, but that forgiveness "must not be confused with the meek toleration of wrongs."13 To disregard the value of our own humanity in this way is not to practice the virtue of forgiveness but rather to commit the vice of servility. ${ }^{14}$ Contemporary writers on forgiveness develop this point by modifying Bishop Butler's account of the function of resentment: Instead of treating it as a defense against moral injuries in general, they focus more specifically on its role in defending our self-respect. According to Pamela Hieronymi, when someone wrongs us, he effectively claims that we are unworthy of being treated decently. The

\footnotetext{
${ }^{11}$ Murphy and Hampton (1988, p. 20).

12 Murphy and Hampton (1988, p. 20).

13 Kant (1996, p. 578 [6:461]). Page numbers in brackets refer to those of the Akademie Edition.

14 Kant (1996, p. 558 [6:436]).
} 
feeling of resentment protests against this claim. To forgo resentment, then, is to run the risk of accepting that claim as legitimate and of viewing oneself as unworthy of basic respect. ${ }^{15}$ This would not be forgiveness at all, but rather servility.

How can we tell in any particular case whether or not forgiveness would reduce to servility? According to one of the recent trends in the literature, exemplified most clearly by Hieronymi’s “Articulating an Uncompromising Forgiveness" and by Charles Griswold's book Forgiveness: A Philosophical Exploration, we can do so by establishing the conditions in which resentment is rationally warranted. According to Hieronymi, we have good reason to resent another person as long as we believe that she persists in thinking of us as unworthy of respect. If the wrongdoer sincerely apologizes, though, we will have good reason to believe that she has given up her belief that we are unworthy of respect, and so the feeling of resentment will no longer be warranted. In that case, we can forgive without compromising our self-respect. ${ }^{16}$ Charles Griswold sets the bar for warranted forgiveness considerably higher, demanding that the wrongdoer satisfy six conditions: she must (1) acknowledge responsibility for the act, (2) express a recognition that the act was morally wrong, (3) express regret for having done it, (4) commit to becoming the sort of person who will no longer do such wrongs, (5) express that she understands the wrong she has done from the victim's point of view, and (6) give an account of why she did the wrong and of why her act does not represent her whole self. ${ }^{17}$

\footnotetext{
15 Hieronymi (2001, p. 546.). Cf. Murphy and Hampton (1988, p. 16).

16 Hieronymi (2001, pp. 546-548).

17 Griswold (2007, pp. 49-51).
} 
If the wrongdoer fails to satisfy these conditions, Griswold thinks, then the victim would have no rational justification to forgive her. To do so would be to condone the wrong and perhaps even to encourage further wrongdoing. ${ }^{18}$

\section{The Electiveness Condition}

In taking such great care to keep the virtue of forgiveness distinct from the vice of servility, though, both of these accounts - and especially Griswold's - lose sight of the elective nature of forgiveness. As Lucy Allais notes, these kinds of accounts treat forgiveness as the giving up of resentment that is no longer rationally warranted and that we therefore ought not to have. But this is less than what we should want from an account of forgiveness. ${ }^{19}$ Specifically, these accounts fail to capture the way in which forgiveness is a gift. We do not need to understand gift here in Derrida's exacting sense as "the unconditional, gracious, infinite, aneconomic forgiveness granted to the guilty as guilty, without counterpart." 20 The point, rather, is simply that it is conceptually possible to forgive people who have not satisfied the kinds of conditions suggested by Hieronymi, Griswold, and others. Indeed when we think of forgiveness as morally praiseworthy, we most likely have in mind this kind of generosity and not the "careful weighing up of evidence about what kind of emotional response the wrongdoer deserves." 21 To miss this

\footnotetext{
18 Alexandra Couto argues for a similar conclusion, making use of Stephen Darwall's idea of the secondperson standpoint in Couto (2016, pp. 1316-1320).

19 Allais (2013, p. 641).

${ }^{20}$ Derrida (2001, p. 34).

21 Allais (2013, pp. 647-648).
} 
gift-character of forgiveness, then, would be to miss something essential to the phenomenon.

Another way to think about the tension between accounts that emphasize the articulateness and uncompromisingness conditions on the one hand and those that emphasize the electiveness condition on the other is that the former suggest what Owen Ware calls a Report View of forgiveness while the latter suggest an Avowal View. On the Report View, forgiveness is primarily an exercise in theoretical reason. ${ }^{22}$ In deliberating about whether or not to forgive, most of our work is devoted to ascertaining the truth of the situation: Has the wrongdoer taken responsibility for her actions? Has she expressed regret? Does it seem likely that she will behave differently in the future? Taken too far, this view of forgiveness would be unduly passive: Once the facts were in, the only choice left would be whether or not to act on the basis of the relevant evidence. As Aurel Kolnai noted in his paper "Forgiveness," this kind of view would render the act of forgiving practically redundant. ${ }^{23}$ But this doesn't seem right: When we forgive, we are more active than that. We experience ourselves as doing something. This intuition is captured by the Avowal View, which understands forgiveness as the exercise not of theoretical but of practical reason. ${ }^{24}$ To forgive, on this understanding, is not primarily to report that the wrongdoer is in fact different from what she used to be; it is to will to view her

\footnotetext{
22 Ware (2014, p. 250).

${ }^{23}$ Kolnai (1973-1974, p. 98).

24 Ware (2014, p. 248).
} 
differently. Accounts that emphasize electiveness attempt to make sense of this important aspect of our experience of forgiveness.

But if we give too much weight to the elective nature of forgiveness, then we take on board exactly those problems that we meant to avoid by insisting on the articulateness and uncompromisingness conditions. First, in separating the will to forgive too much from its justifying reasons, accounts emphasizing electiveness run the risk of reducing forgiveness to mere condonation. Surely to forgive someone is not simply to overlook another's wrongdoing or to treat it as something that is not worth taking very seriously. But that is exactly what forgiveness can look like if the decision to forgive is not closely guided by reasons having to do with the wrongdoer's acknowledgement of responsibility and change of heart. One of the most important considerations supporting the importance of the electiveness condition is that we tend to think of the praiseworthiness of forgiveness as being closely linked to the generosity that it demonstrates toward the wrongdoer. But what looks like generosity from one point of view can look very much like acquiescence from another. And to acquiesce in wrongdoing is to encourage it, which is not praiseworthy at all. To illustrate the seriousness of this worry, let us consult an example that Lucy Allais puts forward as the kind of case that an adequate account of forgiveness should be able to make sense of. The case involves Sicelo Mhlauli, an advocate for justice in apartheid-era South Africa who had been brutally murdered by the police. Mhlauli “was stabbed sixty-eight times with different weapons, had acid poured on his face, and had his hand chopped off and preserved in alcohol at police headquarters in Port Elizabeth, where police referred to it as 'the baboon's hand' and used it to 
intimidate detainees. ${ }^{25}$ At the conclusion of her testimony before the Truth and Reconciliation Commission, his daughter Babalwa Mhlauli said that she wanted to know who was responsible for the murder. Her reason? "“We do want to forgive, but we don't know whom to forgive."' 26 Is this willingness to forgive even in the complete absence of evidence of the unknown wrongdoer's change of heart something we would regard as morally praiseworthy? Is it distinguishable from a willingness to accept the wrong? And if not, is this something we would want to call forgiveness at all? The answer to these questions is not obvious; many writers on forgiveness, it seems, would want to answer no to all three. But even if we believe that Babalwa Mhlauli's act is best characterized as forgiveness, surely there is some threshold beyond which we would want to insist that a forgoing of resentment amounts to nothing more than condonation. ${ }^{27}$

Closely related to these worries is the problem of self-respect. If we choose to forgive a person who has not shown remorse for his wrongdoing or who has not given any sign that he will change his ways for the better, do we not demonstrate a lack of sufficient respect for ourselves and for our own moral standing? Would we not want to say with Kant that such cases are better described as the meek toleration of wrongs rather than as acts of forgiveness? Again, it can be difficult to tell the difference in particular cases, but surely there is some point beyond which we would want to characterize a forgoing of resentment as servility rather than as forgiveness. This is precisely why the

\footnotetext{
25 Lucy Allais (2008, p. 40).

26 Allais (2008, p. 40). The quotation is taken from Tutu (1999, p. 115).

27 Richard Swinburne presents a similar argument in Swinburne (1989, p. 86).
} 
articulateness and uncompromisingness conditions are so important, despite their being in tension with the electiveness condition.

\section{Constitution and Institution}

What I would like to argue in the following two sections is that we can do justice to the three conditions of forgiveness by understanding the phenomenon in terms of Maurice Merleau-Ponty's concept of institution. The concept, which he took up explicitly for the first time in his 1952 essay "Indirect Language and the Voices of Silence," and to which he devoted his 1954-1955 courses at the Collège de France, is developed as a corrective to the philosophy of consciousness, according to which the intelligibility of things has its origin in the meaning-bestowing acts of constituting subjectivity. For the constituting subject, the world given in experience is "at each moment the exact reflection of the acts and powers of consciousness." 28 But as Merleau-Ponty had argued already in Phenomenology of Perception, this idea of constituting consciousness accounts very poorly for our most common, everyday perceptual experience. The perceiving subject is not an absolute consciousness; it is embodied, and so at least to some degree passive, responding to and taking up meanings that are already present, if only latently, in the sensibly given world. To perceive the world, in short, is to perceive according to it, to let oneself be oriented by the sense that it itself adumbrates. This everyday perceptual experience is incompatible with a conception of the constituting subject conceived as

28 Merleau-Ponty (2010, p. 76). 
possessing in advance, "fully realized, all of the knowledge of which our actual knowledge is merely the first approach." 29

In order to begin to engage with the idea of institution on its own terms, it will be helpful to examine the way in which the idea of constituting subjectivity fails to account for the dynamic proper to expression. In the period following the publication of Phenomenology of Perception, Merleau-Ponty's work on the phenomenology of expression comes to be informed by his reading, or perhaps better by his creative misreading, of Saussurian linguistics. One of the central insights of Saussure's Course in General Linguistics is that particular acts of speech (parole) presuppose a linguistic structure (langue). The langue in Saussure's sense is not to be understood as a treasury of terms, each of which corresponds one to one with a given meaning. In the langue, rather, "there are only differences, and no positive terms." ${ }^{30}$ And so the meaning of the term "sheep," for example, is not fixed by its reference to actual sheep that exist in extralinguistic space. It is fixed, rather, by the place of the term within the differential structure of the langue as a whole: It is not a goat or an alpaca or mutton, etc. ${ }^{31}$ The most important lesson from all this, for present purposes at least, is that the speaking subject cannot constitute the meaning "sheep." In order even to be able to intend something determinate like "sheep" at all, the speaker must rely on a whole system of differences that he could not possibly have constituted. "The langue," Saussure insists, "is not a function of the

\footnotetext{
29 Merleau-Ponty (2012, p. 42).

${ }^{30}$ Saussure (1986, p. 118). Translation modified. Emphasis omitted.

31 Saussure (1986, p. 114).
} 
speaking subject; it is the product that the individual registers passively." 32 Of course the speaking subject can attempt to modify the meaning of specific terms within the langue, but doing so would still presuppose the linguistic system that he wants to change. If he does not respect the ordered system of differences that makes up the langue, he will produce nonsense, and so he will express nothing intelligible at all. The speaking and intending subject, then, finds himself always already in the midst of a source of meaning that he cannot have constituted and that he must respect.

When Merleau-Ponty takes up the work of Saussure in his lectures and texts from the late 1940s and early 1950s, he rejects the sharp dualism of langue and parole that we find in the Course in General Linguistics. For Saussure, individual speech acts are merely manifestations of the linguistic structure in something like the way an orchestra's performance of a symphony is a manifestation of the symphony itself. "The symphony," he insists, "has a reality of its own, which is independent of the way in which it is performed." 33 The performance is "ancillary and more or less accidental." 34 MerleauPonty, on the other hand, treats langue and parole (or in his own terminology, spoken language and speaking language) as two different manifestations of the same thing, and not as ontologically distinct realities. On his account, the two sides of the phenomenon of language stand in a quasi-dialectical relation, such that spoken language envelops the

\footnotetext{
32 Saussure (1986, p. 14). Translation modified.

33 Saussure (1986, p. 18).

34 Saussure (1986, p. 14).
} 
speaking subject while at the same time being enveloped by it. ${ }^{35}$ The first part of the relation - the envelopment of the speaking subject by the already existing system of language - is the one that Saussure's work emphasizes. But for Merleau-Ponty, the spoken language is not a rigid differential structure that the speaking subject registers passively. He understands it instead as a nascent, open-ended, expressible but not yet determinately expressed dimension of sense that is experienced only vaguely by the speaking subject as "a precise uneasiness in the world of things-said."36 The speaking subject, on this account, is actively passive: In order to express herself, she must be sensitive to the latent sense within which she finds herself always already, but she must also take up this sense, bringing it to determinacy with the help of her meaningbestowing intention. This is reflected in the experience of anyone who has struggled to give expression to a novel thought: We have an intimation that there is something to be said, but this something is present only vaguely. We strain toward what we want to say, trying out various formulations in an effort to capture the sense that solicits us. Sometimes we hit on exactly the right expression, and the sense that had been given nascently is captured in an articulated signification. In these cases of successful expression, it seems to us as if the correct formulation had been there all along, and that we had merely discovered it. But this is an illusion. We have neither discovered a meaning that was already there, fully formed, nor created it ex nihilo. In giving

\footnotetext{
35 Merleau-Ponty (1973, p. 24). Merleau-Ponty refers here to an "envelopment of language by language," an idea he attributes to Saussure. This envelopment "attests to a permanent affinity between my speaking and the language about which I am speaking."

36 Merleau-Ponty (1964a, p. 19).
} 
expression to a sense that is present as intimated, we are irreducibly passive and active, "receiving and giving in the same gesture." 37

And this brings us right up to the idea of institution. In his lecture course at the Collège de France titled Institution and Passivity, Merleau-Ponty tells us that institution refers to "those events in an experience which endow the experience with durable dimensions, in relation to which a whole series of other experiences will make sense, will form a thinkable sequel or a history." ${ }^{\prime 3}$ To unpack what this means, we can return to the experience we have when we strive to give expression to a new thought. We begin with the intimation of sense as being in a precariously stable state, i.e., one in which there is some degree of tension between the sense that is expressible and the sense that has already been successfully expressed. ${ }^{39}$ By contrast, a stable state of sense would be one in which all the sense that is expressible has already been expressed. In such a state, expression would be nothing more than the transmission of signs standing for fully transparent significations of which the speaking subject would already be in full possession. But genuine expression is not like this. The vaguely given sense that we begin with is experienced as soliciting us and as calling for determinate expression. When we succeed in giving expression to this sense, we do not put the whole of sense into a stable equilibrium, such that there would be no more sense to express. Instead we bring about a new precariously stable state that functions as the background for new

\footnotetext{
37 Merleau-Ponty (1973, p. 11).

38 Merleau-Ponty (2010, p. 77).

39 Landes (2013, p. 25).
} 
solicitations and for previously unforeseen possibilities of expression. Or in the language of Merleau-Ponty's definition, we “endow the experience with durable dimensions, in relation to which a whole series of other experiences will make sense, will form a thinkable sequel or a history.”

But this first approach to the idea of institution might give a somewhat misleading impression, suggesting as it does that it is the subject who opens up new and unforeseen dimensions of experience. This is not entirely false, of course. Expression is not something that happens to the subject; it requires the activity of a subject with some kind of meaning-bestowing intention. Nonetheless, Merleau-Ponty tells us that it is events that endow experience with durable dimensions. Institution, he thinks, happens in accordance with a "subterranean logic" that is not entirely accessible to the subject. ${ }^{40}$ We can see this especially clearly in our affective comportment toward the world. As Kym Maclaren notes, our emotions "often take hold of us in ways that we cannot shake by simply, stoically, choosing a different attitude." 41 In other words, we cannot reconstitute the sense of the situations we find ourselves in by means of unilateral acts of sense-bestowal. Instead, emotional transformations typically "happen in unexpected ways, and by virtue of some contingent event that suddenly brings upon us, as if from beyond us, an epiphany. Suddenly, we experience a revolution not just in our thoughts but in our very

\footnotetext{
${ }^{40}$ Merleau-Ponty (2010, p. 77).

41 Maclaren (2017, p. 67).
} 
being, at the existential level." 42 This point is exemplified nicely by a case of childhood jealousy that Merleau-Ponty describes in "The Child's Relations with Others:"

The younger of two children shows jealousy when his new [sister] is born.

During the first days of the newborn child's life, he identifies with it, carrying

himself as though he himself were the newborn baby. There is a striking

regression in language as well as in character. ${ }^{43}$

The child, whose name is Gricha, regresses because the familial world within which he has always found his bearings is the one in which he acts and is treated as the youngest. Faced with the challenge effected by the birth of his younger sister, the boy tries to reestablish the system of relations that he knows how to navigate: He acts like the youngest. But this fails, as his family make clear to him that they expect a different kind of behavior from him. The boy responds to this setback by imitating his older brother Jean, but this does not work either. So far there has been no institution of new dimensions of experience for Gricha, as he still experiences his world as structured by the absolute positions of youngest and oldest. This structure is now problematic in a way that it hadn't been before: He can only think of himself as occupying one of two positions, but he cannot effectively occupy either. And he lacks the resources to reconstitute the meaning of his situation in a way that would resolve the tension he experiences. The tension is resolved only with the help of a fortuitous event: Another boy, Serge, who is older than all three of the siblings, comes over to play. This event endows the boy's experience with

\footnotetext{
42 Maclaren (2017, p. 67).

${ }^{43}$ Merleau-Ponty (1964b, p. 109). Merleau-Ponty mistakenly characterizes the boy's younger sibling as a brother. The case is described in more detail in Dolto-Marette (1947, pp. 524-530). Kym Maclaren argues convincingly that this case exemplifies institution, despite Merleau-Ponty's not using that term in his description, in Maclaren (2017, pp. 67-72).
} 
durable new dimensions, as he becomes capable of recognizing positions within social space as relative and not as absolute. His older brother is older than him but younger than the visiting friend. Likewise, he himself is older than the newborn baby but younger than his older brother. This new sense was not simply there, waiting for the boy to discover it. Nor did he create it ex nihilo. Rather the boy "infuse[d] a new meaning into what nevertheless called for and anticipated it."44 Once this institution was realized, the boy's jealousy disappeared.

\section{Forgiveness as Institution}

I believe that this same kind of subterranean logic describes what happens in cases of forgiveness. To show how this is the case, it will be helpful to begin with the initial wrongdoing, which we can understand as an event that endows the experience of the victim and of the wrongdoer "with durable dimensions, in which a whole series of other experiences will make sense." The wrongdoing, in other words, is itself an institution. As Pamela Hieronymi suggested, the offended party will come to feel resentment toward the wrongdoer, viewing him as an ongoing threat to her self-respect. She will likely treat the act as expressive of the wrongdoer's enduring character, and so she will view him as someone with whom it will be impossible to relate in a mutually respectful way. She will treat him with less consideration and empathy than before, and will probably withdraw from him as much as is practically possible. In viewing the wrongdoer in this way, the offended party does not constitute the new sense of their

\footnotetext{
44 Merleau-Ponty (1973, p. 68).
} 
relationship in a unilateral act of sense-bestowal. Her attitude rather takes up and carries forward the momentum of a sense that is already there.

But to say that the wrong opens up a future with durable dimensions is not to say that it determines the future. The parties to the relationship cannot carry the instituted sense forward by mechanically repeating it because, as we have seen, there is no "it" to repeat. All the elements of the instituted sense - the meaning of the act, its expressiveness of the wrongdoer's character, whether "but for the grace of God" the offended party may have acted similarly in similar circumstances, the level of the threat posed to her selfrespect, etc. - are open-ended. The parties will be able to bestow more determinate sense on these elements only retroactively, as a function of the ways they choose to carry the nascent sense forward. Although they cannot successfully bestow sense in any way they might like, they can institute something relatively new, opening up dimensions that call for a future different from the one that seemed to have been fixed in place by the initial wrong.

Of course one way to open up the possibility for a different future is to forgive. This is easy to see in cases where the wrongdoer apologizes or gives other clear evidence of having had a genuine change of heart. These signs have a retroactive effect, revising the sense of the wrong and of the threat it poses. Specifically, it gives the offended party reason to believe that the wrong was not expressive of the wrongdoer's enduring character. If it is true that resentment is best understood as a defense against disrespect, then that feeling no longer seems appropriate in the state of affairs following the apology. The situation now calls for forgiveness instead. But I want to argue, against those 
philosophers who strongly emphasize the articulateness and uncompromisingness conditions, that forgiveness can be called for even without the wrongdoer's having apologized. Here, I believe, comparison with the case that Merleau-Ponty described in "The Child's Relations with Others" is especially instructive. Following the birth of his younger sister, Gricha tries to carry forward his sense of himself as the youngest. This fails, though, and the result is that Gricha's lived relationship to his younger sister is shaped through and through by the feeling of jealousy. Gricha cannot resolve the tension within his familial relations simply by reconstituting its sense in terms of the logic of relative, as opposed to absolute, positions. Of course part of the reason he cannot do so is that he is a very young child and the logic of the new situation is too complex for him to grasp. But even if he were more cognitively sophisticated, it would not suffice simply to explain the new logic to him and to advise him to think of his relationship to his siblings accordingly. This is because our considered judgments about what is best do not always reach deeply enough to determine our lived experience. What does succeed in changing Gricha's experience is a fortuitous and seemingly trivial event—Serge's coming over to play — which casts his situation in a new light, crystallizing his sense of his place within the family in a way that resolves the tension he had been struggling with. Similarly in the case of forgiveness, it might happen that the wrongdoer does a small act of kindness for the offended party, or that he smiles as they pass in the hallway. These are not unambiguous signs, but they are at least intimations that a different kind of future might be possible. Or maybe the offended party has an experience that reveals to her a tendency to overestimate the malicious intent behind perceived slights. This realization need not 
overturn her conviction that she had in fact been wronged, but it at least suggests the possibility of relating to the wrongdoer in a different way. In light of such intimations, the offended party might experience a pull toward taking the initiative to restore the damaged relationship. She might do this simply by making small talk with the wrongdoer or by returning his smile in the hallway. In giving these signs, she takes up and attempts to carry forward the nascent sense of their relationship, contributing in a small but important way toward opening up a future in which relations of good will and mutual respect come to appear as real possibilities. The forgiveness here would consist in this event of institution. It does not require an explicit declaration that the wrongdoer is forgiven any more than Gricha's new relationship with his siblings requires an explicit declaration that he will henceforth behave in accordance with his position as the middle child. ${ }^{45}$ This conception of forgiveness as institution is somewhere between a Report View and an Avowal View. It is similar to an Avowal View in that the forgiver must perform an act of creative sense-bestowal. The act of forgiveness, in other words, is something more than the practical acknowledgment that the wrongdoer has in fact satisfied a checklist of conditions; it effects a new kind of relationship through a commitment to view the wrongdoer differently. It is unlike an Avowal View, though, in that it emphasizes to a much greater degree the subject's implication within a dimension of sense that exceeds him and that has a dynamic of its own. According to Owen Ware's version of the Avowal View, we can forgive a wrongdoer by foregrounding our recognition respect for her, rendering her dignity as a person more salient and

\footnotetext{
45 Murphy and Hampton (1988, pp. 42-3); Neblett (1974, p. 269).
} 
backgrounding the bad acts that had given rise to our resentment. ${ }^{46}$ Just as in the case of visual perception, though, there must be something in the sense of the situation that supports our treating some aspect as foreground and others as background. If nothing in our experience calls in any way for this kind of change in our attitude toward the wrongdoer, then the forgiveness we attempt to grant will not take. And this is precisely what makes the account of institution as forgiveness somewhat similar to a Report View. But it is importantly different from a Report View in that the sense of the situation to which the act of forgiveness responds is not fully determinate. Again, there is no checklist of conditions that the wrongdoer must satisfy. The sense of the relationship between the wrongdoer and the victim, rather, is precariously stable, capable of being taken up and carried forward in multiple ways. The act of forgiveness responds to the sense that is already there, then, but it also contributes toward stabilizing it. Or in Merleau-Ponty's terms once again, the forgiving subject is "receiving and giving in the same gesture."

One important advantage of this institution-based understanding of forgiveness is that it accounts well for an experience that is underemphasized by many philosophers, who tend to over-intellectualize the phenomenon: 47 Very frequently, the question we face when we respond to another's serious wrongdoing is not "should I forgive?" but rather "can I forgive?" As David Sussman notes, "the possibility here turns not on whether there are good enough reasons to forgive, but upon what one can bring oneself to do, what one

\footnotetext{
46 Ware (2014, p. 254).

47 Allais (2013, p. 637).
} 
can live with, how one can see or come to see the supplicant." 48 David Novitz makes a similar point when he writes that "forgiveness does not consist in any one act that a person can perform at will and that directly results in the banishment of hard feelings." 49 This is precisely because forgiveness is not the sense-bestowing act of a constituting subject. The subject who would forgive, rather, is like the writer who has an intimation that there is some thought to be expressed, that some sense is vaguely soliciting her, but who must struggle with language until the sense crystallizes. She cannot bring the intimated sense to expression all at once by an act of will. Indeed, she may not be able to give adequate expression to the intimated sense at all. If the sense is brought to successful expression, this will happen as an event in which the subject is as passive as she is active. This point about institution generally is especially pertinent to the case of forgiveness, where the victim's perception of the wrongdoer is shaped to such a great degree by the feeling of resentment, which is deep seated and which resists our best efforts simply to will it away.

The other major advantage of the account that treats forgiveness as institution, finally, is that it satisfies the articulateness, uncompromisingness, and electiveness conditions. Let us begin with the latter. Like all kinds of institution, forgiveness attempts to bring into being a state of affairs that does not already exist, with no guarantee that the attempt will succeed. In The Prose of the World, Merleau-Ponty describes the way in which artistic institution is necessarily addressed to a public that does not yet exist. The

\footnotetext{
48 Sussman (2005, pp. 90-91).

49 Novitz (1998, p. 308).
} 
artist, he says, must draw the public "toward values in which they will only later recognize their own values." 50 But sometimes artistic innovations turn out to be deadends: the artist feels called upon to play the sedimented sense forward in a particular way, but the public does not follow. When that happens, the attempted institution fails, as no thinkable sequel or history is effectively opened up. The same kind of thing can happen with forgiveness: Responding to hints in the already instituted sense of her history with the wrongdoer, the forgiver launches herself into an uncertain future toward which, if her act succeeds, both parties will come to view their relationship as having been destined all along. But she cannot be certain that her act will succeed in instituting this future. In taking the leap, she goes beyond what is rationally required or even rationally justified. In this sense her act is elective. But because the forgiver acts in response to the sense of the relationship she has with the wrongdoer-even though this sense is given as nascent and open-ended - the forgiveness is also articulate. This means, at very minimum, that it is not the result of mere forgetfulness or distraction. But it also means that in forgoing resentment, we are doing something more than just manipulating our own emotions; we are acting in a way that is sensitive to our judgments about the wrongdoer, so that we are in a position to give reasons justifying our forgiveness. ${ }^{51}$ Because the act of forgiveness is elective, though, there is always a possibility that our reasons were not as good as we had thought they were. And this means that there can be no guarantee that forgiveness will be uncompromising. For example, a person's attempt at forgiveness might end up, for

\footnotetext{
${ }^{50}$ Merleau-Ponty (1973, p. 86).

51 Cf. Hieronymi (2001, p. 536).
} 
reasons outside her control, appearing to the wrongdoer as acquiescence to the disrespectful treatment or as signaling that the wrong was not very serious. Perhaps the forgiver will have misread the signs of the wrongdoer's good will because of an unacknowledged desire to avoid conflict or to be accepted by him. Perhaps. After all, none of us are fully transparent to ourselves. Nonetheless, there is no reason in principle to believe that attempts to forswear resentment and to reconcile with potentially unrepentant wrongdoers necessarily express a lack of self-respect or a belief that the wrong was not very serious. If forgiveness is something more than a highly coded, quasiadministrative procedure for reconciling relationships - if, as Lucy Allais suggests, it is essentially an act of generosity - then there can be no forgiveness that is not at least somewhat risky. ${ }^{52}$ This is a feature it shares with all acts of institution. And so the attempt to forgive without having received an apology no more expresses a lack of self-respect than the attempt of an artist to institute new literary or painterly sense, without the guarantee of success, expresses a lack of artistic integrity. Of course the account of forgiveness as institution cannot show that forgiveness is necessarily uncompromising. But I do not believe any adequate account of forgiveness could show that. What such an account can show, though, is that electiveness, articulateness, and uncompromisingness are perfectly compatible, and it can do so without presenting an unnecessarily deflationary view of any of these conditions. And this, I believe, gives it a plausible claim to being a more successful account of forgiveness than its rivals.

\footnotetext{
52 Cf. North (1987, p. 505): "If I am to forgive I must risk extending my trust and affection, with no guarantee that they will not be flung back in my face or forfeited again in the future. One might even say that forgiveness is an unconditional response to the wrongdoer, for there is something unforgiving in the demand for guarantees."
} 


\section{WORKS CITED}

Allais, Lucy. 2013. Elective Forgiveness. International Journal of Philosophical Studies 21(5): 637-653.

Allais, Lucy. 2008. Wiping the Slate Clean: The Heart of Forgiveness. Philosophy \& Public Affairs 36(1): 33-68.

Butler, Joseph. 2006. Fifteen Sermons in The Works of Bishop Butler. Ed. David E. White. Rochester, NY: University of Rochester Press.

Couto, Alexandra. 2016. Reactive Attitudes, Forgiveness, and the Second-Person Standpoint. Ethical Theory and Moral Practice 19(5): 1309-1323.

Derrida, Jacques. 2001. On Cosmopolitanism and Forgiveness. Trans. Mark Dooley and Michael Hughes. London: Routledge.

Dolto-Marette, Françoise. 1947. Hypothèse nouvelle concernant les réactions dites de jalousie à la naissance d'un puîné. Psyché 7: 524-530.

Griswold, Charles. 2007. Forgiveness: A Philosophical Exploration. Cambridge: Cambridge University Press.

Hieronymi, Pamela. 2001. Articulating an Uncompromising Forgiveness. Philosophy and Phenomenological Research 62(3): 529-555.

Jankélévitch, Vladimir. 2005. Forgiveness. Trans. Andrew Kelley. Chicago: University of Chicago Press.

Kant, Immanuel. 1996. The Metaphysics of Morals in Practical Philosophy, The Cambridge Edition of the Works of Immanuel Kant. Ed. and trans. Mary J. Gregor. Cambridge: Cambridge University Press.

Kekes, John. 2009. Blame versus Forgiveness. The Monist 92(4): 488-506.

Kolnai, Aurel. 1973. Forgiveness. Proceedings of the Aristotelian Society 74: 91-106.

Landes, Donald A. 2013. Merleau-Ponty and the Paradoxes of Expression. London: Bloomsbury.

Maclaren, Kym. 2017. The 'Entre-Deux' of Emotions: Emotions as Institutions in Kirsten Jacobson and John Russon, eds., Perception and its Development in Merleau-Ponty's Phenomenology. Toronto: University of Toronto Press.

Merleau-Ponty, Maurice. 2012. Phenomenology of Perception. Trans. Donald A. Landes. New York: Routledge.

Merleau-Ponty, Maurice. 2010. Institution and Passivity: Course Notes from the Collège de France (19541955). Trans. Leonard Lawlor and Heath Massey. Evanston: Northwestern University Press. 
Merleau-Ponty, Maurice. 1973. The Prose of the World. Ed. Claude Lefort; trans. John O'Neill. Evanston: Northwestern University Press.

Merleau-Ponty, Maurice. 1964a. Signs. Trans. Richard C. McCleary. Evanston: Northwestern University Press.

Merleau-Ponty, Maurice. 1964b. The Primacy of Perception. Ed. James M. Edie. Evanston: Northwestern University Press

Murphy, Jeffrie G. and Jean Hampton. 1988. Forgiveness and Mercy. Cambridge: Cambridge University Press.

Neblett, William R. 1974. Forgiveness and Ideals. Mind 83(330): 269-275.

North, Joanna. 1987. Wrongdoing and Forgiveness. Philosophy 62(242): 499-508.

Novitz, David. 1998. Forgiveness and Self-Respect. Philosophy and Phenomenological Research 58(2): 299-315.

Saussure, Ferdinand. 1986. Course in General Linguistics. Trans. Roy Harris. Chicago: Open Court.

Swinburne, Richard. 1989. Responsibility and Atonement. Oxford: Oxford University Press.

Tutu, Desmond. 1999. No Future Without Forgiveness. London and Johannesburg: Random House.

Ware, Owen. Forgiveness and Respect for Persons. American Philosophical Quartlerly 51(3): 247-260.

Zaibert, Leo. 2009. The Paradox of Forgiveness. Journal of Moral Philosophy 6(3): 365-393. 